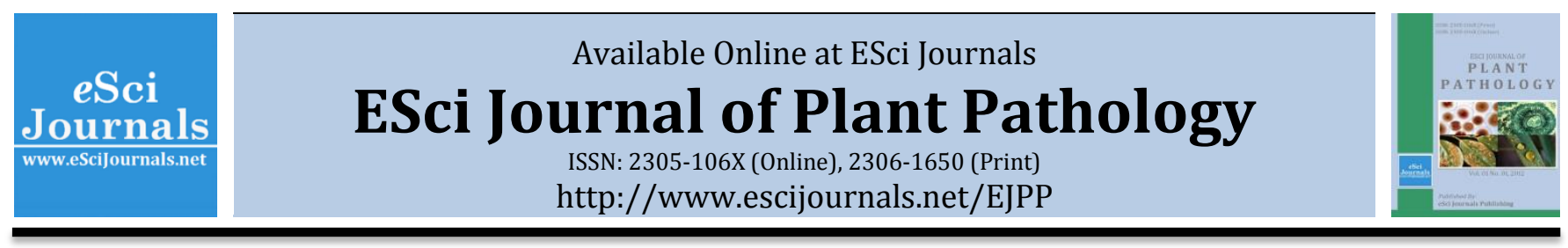

\title{
EFFECT OF STEM RUST INFECTION ON GRAIN YIELD AND YIELD COMPONENTS OF SOME WHEAT CULTIVARS IN EGYPT
}

\author{
aMamdouh A. Asmmawy, aWalid M. El-Orabey, bMohamed Nazim, aAtef A. Shahin \\ a Wheat Diseases Research Department, Plant Pathology Research Institute, Agricultural Research Center, Giza, Egypt. \\ b Faculty of Agriculture, Minufiya University, Shibin El-Kom, Egypt.
}

\section{A B S T R A C T}

Stem rust, caused by Puccinia graminis f. sp. tritici is an important disease of wheat worldwide. To estimate grain yield losses due to stem rust, replicated experiments including twelve wheat cultivars i.e. Gemmeiza 7, Gemmeiza 9, Gemmeiza 10, Gemmeiza 11, Sakha 61, Sakha 93, Sakha 94, Sids 12, Sids 13, Giza 168, Misr 1 and Misr 2 were evaluated for adult plant resistance at Sakha Research Station, Kafr El-Sheikh, Egypt during 2011/12 and 2012/13 growing seasons. The field experiment was surrounded by spreader area of highly susceptible varieties i.e. Morroco and Max inoculated with a mixture of stem rust races as a source of inoculum. Disease severity was recorded each 10 days and area under disease progress curve (AUDPC) was estimated and ranged from 100 to 475 in 2011/12 and 100 to 750 in 2012/13. It was found that, yield losses ranged between $2.47 \%$ in the wheat cultivar Misr 2 to $6.29 \%$ in the wheat cultivar Sids 12 during 2011/12, while during 2012/13 ranged from $1.96 \%$ in the wheat cultivar Gemmeiza 7 to $8.21 \%$ in the wheat cultivar Misr 1. High correlation was found between yield losses with disease severity and AUDPC.

Keywords: Wheat, Puccinia graminis, partial resistance, yield losses.

\section{INTRODUCTION}

Stem rust caused by Puccinia graminis f. sp. tritici, is the most destructive disease to wheat. Under favorable conditions, stem rust may cause yield losses up to $100 \%$ to the susceptible varieties (Roelfs, 1985 \& Leonard and Szabo, 2005).

The new stem rust race which was designated as Ug99 in Uganda in 1999 has threatened wheat production globally (Pretorius et al., 2000). Wanyera et al. (2006) designated this strain as race TTKS using the letter code stem rust nomenclature system (Roelfs and Martens 1988). A fifth set of differential lines was added, thus Pgt-Ug99 is race TTKSK and variants with added virulence to $\mathrm{Sr} 24$ and $\mathrm{Sr} 36$ are TTKST and TTTSK, respectively (Jin et al. 2008, 2009). Four other variants of the Ug99 race lineage (TTKSF, TTKSP, PTKSK, and PTKST) are present in different parts of Africa (Park et al. 2011). Race TTKSK and its variants are virulent to about $90 \%$ of the world's wheat cultivars (Singh et al. 2008). Race Ug99 is virulent to a number of stem rust

\section{* Corresponding Author:}

Email: walid_elorabey@hotmail.com

(C) 2013 ESci Journals Publishing. All rights reserved. resistance genes, most notably $\mathrm{Sr} 31$ for which Ug99 was the first reported virulent race. Also, Ug99 is highly damaging which was reported to cause yield losses of more than $71 \%$ in experimental fields (CIMMYT, 2005). Host resistance is the effective control method for stem rust and has been used worldwide for over 50 years, but TTKSK is virulent to most $\mathrm{Sr}$ genes (Jin et al. 2007). Among 56 designated and a few undesignated stem rust resistance genes in wheat, only eight designated genes in the primary gene pool $(S r 13, S r 14, S r 22, S r 28, S r 33$, $S r$ 35, Sr 42, and Sr 45) confer resistance to TTKSK (Pretorius et al. 2000; Jin et al. 2007; Hiebert et al. 2011). Although host resistance to stem rust has generally provided adequate protection without the need for chemicals (Loughman et al., 2005 and Singh et al., 2008), it is important to evaluate popular commercial cultivars and other improved wheat varieties that may have the potential to replace current susceptible varieties (Pretorius et al., 2007).

The objectives of the present investigation were:1- To examine the reaction of 12 commercial wheat cultivars to stem rust under field conditions.

2- To assess yield losses due to stem rust infection in 12 
wheat cultivars when exposed to high stem rust pressure.

\section{MATERIALS AND METHODS}

This experiment was carried out at Sakha Agricultural Research Station in two successive growing seasons i.e. 2011/12 and 2012/13, using 12 wheat cultivars i.e. Gemmeiza 7, Gemmeiza 9, Gemmeiza 10, Gemmeiza 11, Sakha 61, Sakha 93, Sakha 94, Sids 12, Sids 13, Giza 168, Misr 1 and Misr 2. The wheat cultivars were grown in a randomized complete block design with three replicates. The plot size was $6 \times 7 \mathrm{~m}=42 \mathrm{~m}^{2}$, each plot contained 20 rows with $7 \mathrm{~m}$ long and $30 \mathrm{~cm}$ between rows. The experiment was planted 15 days after the regular sowing date (the first half of December) to expose the plants to suitable environment of rust incidence and development.

Plots were surrounded by spreader area planted with a mixture of highly susceptible wheat genotypes to stem rust i.e. Morocco and Max to spread inoculum. To provide and maintain the rust inoculum pressure the experiment was also inoculated by injection method twice in a week during the growing season. To maintain crop stand/vigor normal agronomic practices including recommended fertilization dose and irrigation schedule were followed. To keep protected plots almost free from stem rust, the fungicide Sumi-eight 5 EC $(1 \mathrm{H}-1,2,4-$ Triazole-1-ethanol,.beta.-[(2,4-dichlorophenyl)methylene] -.alpha.-(1,1-dimethylethyl)-,(.beta.E) (35 cm /100 litter water) was applied at 10, 26 February and 8 March.

Stem rust severity and reaction were evaluated for each plot every 10 days intervals from rust appearance along with the stages of plant growth using the modified Cobb's scale (Peterson et al., 1948) and the host response scale described in Roelfs et al. (1992).

The area under disease progress curve (AUDPC) was calculated for each variety according to the equation adopted by Pandy et al. (1989).

AUDPC $=\mathrm{D}\left[1 / 2\left(\mathrm{Y}_{1}+\mathrm{Y}_{\mathrm{k}}\right)+\left(\mathrm{Y}_{2}+\mathrm{Y}_{3}+\cdots+-\cdot+\mathrm{Y}_{\mathrm{k}-1}\right)\right]$

Where: $\mathrm{D}=$ days between two consecutive records (time intervals)

$\mathrm{Y}_{1}+\mathrm{Y}_{\mathrm{k}}=$ Sum of the first and last disease records.

$\mathrm{Y}_{2}+\mathrm{Y}_{3}+\ldots+\mathrm{Y}_{\mathrm{k}-1}=$ Sum of all in between disease scores.

Table 1: List of the local wheat cultivars that were used, pedigree and year of release.

\begin{tabular}{|c|c|c|c|}
\hline No. & Variety & Pedigree & $\begin{array}{l}\text { Year of } \\
\text { release }\end{array}$ \\
\hline 1 & Gemmeiza 7 & CMH74A.630/SX//SER182/3/AGENT. GM4611-2GM-3GM-1GM-0GM. & 1999 \\
\hline 2 & Gemmeiza 9 & ALD"S"/HUAC"S"//CMH74A.630/SX. GM4583-5GM-1GM-0GM. & 1999 \\
\hline 3 & Gemmeiza 10 & $\begin{array}{l}\text { MAYA74"S"/0N//160-147/3/BB/GLL/4/CHAT"S"/5/ CROW"S". GM5820- } \\
\text { 3GM-1GM-2GM-0GM. }\end{array}$ & 2004 \\
\hline 4 & Gemmeiza 11 & $\begin{array}{l}\text { B0W"S"/KVZ"S"//7C/SERI82/3/GIZA168/SAKHA61. GM7892-2GM-1GM- } \\
\text { 2GM-1GM-0GM. }\end{array}$ & 2011 \\
\hline 5 & Sakha 61 & INIA/RL4220//7C/YR"S"CM15430-2S-5S-0S-0S & 1980 \\
\hline 6 & Sakha 93 & Sakha 92/TR 810328 S 8871-1S-2S-1S-0S & 1999 \\
\hline 7 & Sakha 94 & $\begin{array}{l}\text { OPATA/RAYON//KAUZ.CMBW90Y3280-0TOPM-3Y-010M-010M-010Y- } \\
\text { 10M-015Y-0Y-0AP-0S. }\end{array}$ & 2004 \\
\hline 8 & Giza 168 & MIL/BUC//Seri CM93046-8M-0Y-0M-2Y-0B & 1999 \\
\hline 9 & Sids 12 & $\begin{array}{l}\text { BUC//7C/ALD/5/MAYA74/ON//1160-147/3/BB/GLL/4/ } \\
\text { CHAT"S"/6/MAYA/VUL//CMH74A.630/4*SX.SD7096-4SD-1SD-1SD-0SD. }\end{array}$ & 2007 \\
\hline 10 & Sids 13 & $\begin{array}{l}\text { KAUZ "S"//TSI/SNB"S". ICW94-0375-4AP-2AP-030AP -0APS-3AP-0APS- } \\
\text { 050AP-0AP-0SD. }\end{array}$ & 2010 \\
\hline 11 & Misr 1 & $\begin{array}{l}\text { OASIS/SKAUZ//4*BCN/3/2*PASTOR. CMSSOYO1881T-050M-030Y- } \\
\text { O30M-030WGY-33M-0Y-0S. }\end{array}$ & 2011 \\
\hline 12 & Misr 2 & SKAUZ/BAV92. CMSS96M0361S-1M-010SY-010M-010SY-8M-0Y-0S. & 2011 \\
\hline
\end{tabular}

At maturity the crop was harvested and yield of each cultivar of $42 \mathrm{~m}$ was weighted by conventional balance. The influence of stem rust severities on yield was determined by comparing the yield of infected and protected cultivars. Yield loss was estimated using the simple equation as follows:-

Loss \% = 1-yd/yh X 100 (Colpauzos et al., 1976).

Where: $Y d=$ yield of diseased plants. 
$\mathrm{Yh}=$ yield of healthy plants.

Data of 1000-kernel weight (g) and grain yield (kg) was calculated following Hassan (2004). Randomly selected thousand kernel from each entry were counted with a seed counter and were weighed with an electronic balance to calculate 1000-kernel weight. The grain weight from the threshed spikes was measured entire harvested plots was weighed with an electronic balance to calculate grain yield per plot for each cultivar.

Least significant differences (L.S.D. at 5\%) was used to compare yield components according to (Snedecor, 1957). Correlation coefficient was also used to detect the relationship between yield loss and AUDPC.

\section{RESULTS AND DISCUSSION}

The present study clearly showed that the wheat cultivars showed high stem rust disease severity exhibited maximum values of AUDPC and yield losses. While the wheat cultivars showed low disease severity displayed minimum values of AUDPC and yield losses. It was also evident that the susceptible wheat cultivars suffered more yield losses than those of moderately resistant to resistant to stem rust.

Reaction of commercial wheat cultivars to stem rust: The reaction of the commercial wheat cultivars to stem rust at adult plant stage under field conditions is shown in Tables 2 and 3.

The fungicide-protected plots remained almost free from stem rust during the two growing seasons of this study (2011/12 and 2012/13).

In 2011/12 growing season, all of the tested wheat cultivars showed different disease severity ranged from 5 to $30 \%$ (Tables 2 and 3). The cvs. Gemmeiza 9, Gemmeiza 10 and Sakha 94 showed the least disease severity (10 R), followed by Misr 1 and Misr 2 (10 MR and $10 \mathrm{MS}$ ). While, the rest of the tested cvs. exhibited rust severity ranged from $5 \%$ to $30 \%$.

Table 2: Effect of stem rust infection on yield components of 12 Egyptian wheat cultivars at Sakha agricultural research station during season 2011/12.

\begin{tabular}{lcccccccc}
\hline \multirow{2}{*}{ Cultivar } & $\begin{array}{c}\text { Final rust } \\
\text { severity (\%) }\end{array}$ & \multirow{2}{*}{ AUDPC } & \multicolumn{2}{c}{ 1000 kernel weight (gm) } & \multicolumn{3}{c}{ Plot weight (kg) } \\
\cline { 5 - 9 } & & Infected & Protected & Loss (\%) & Infected & Protected & Loss (\%) \\
\hline Gemmeiza7 & 5 S & 100 & 42.60 & 43.70 & 2.52 & 17.20 & 17.75 & 3.10 \\
Gemmeiza9 & $10 \mathrm{R}$ & 145 & 43.50 & 44.40 & 2.03 & 22.43 & 23.00 & 2.48 \\
Gemmeiza10 & 10 R & 145 & 41.38 & 42.30 & 2.17 & 23.13 & 23.75 & 2.61 \\
Gemmeiza11 & $10 \mathrm{~S}$ & 165 & 42.39 & 43.50 & 2.55 & 24.53 & 25.25 & 2.85 \\
Sakha 61 & 5 S & 100 & 39.50 & 41.12 & 3.94 & 13.80 & 14.50 & 4.83 \\
Sakha 93 & 10 S & 165 & 37.13 & 39.50 & 6.00 & 20.35 & 21.50 & 5.35 \\
Sakha 94 & 10 R & 145 & 43.74 & 44.80 & 2.37 & 21.65 & 22.25 & 2.70 \\
Giza 168 & 10 S & 145 & 42.74 & 44.34 & 3.61 & 23.54 & 24.50 & 3.92 \\
Sids 12 & 30 S & 475 & 41.74 & 44.74 & 6.71 & 22.96 & 24.50 & 6.29 \\
Sids 13 & 20 S & 325 & 41.20 & 43.40 & 5.07 & 22.35 & 23.75 & 5.89 \\
Misr 1 & 20 MR & 215 & 40.40 & 41.50 & 2.65 & 22.48 & 23.20 & 3.10 \\
Misr 2 & 10 MS & 145 & 41.30 & 42.16 & 2.04 & 22.53 & 23.10 & 2.47 \\
\hline L.S.D. at 5\% & & & 0.156 & & & 0.163 & & \\
\hline
\end{tabular}

In 2012/13 growing season, all of the tested cultivars exhibited susceptible infection type. The cvs. Gemmeiza 7, Sakha 61, Gemmeiza 9, Gemmeiza 10, Gemmeiza 11, Giza 168, Sakha 93 and Sakha 94 showed rust severity ranged from $5 \mathrm{~S}$ to $10 \%$. While, the cvs. Sids 13, Sids 12 Misr 1 and Misr 2 showed higher rust severity ranged from 20 to $40 \%$. Denbel et al., (2013) found that the wheat variety Pavon 76 was resistant at adult plant stage and has low terminal rust severity (30 MS) under heavy stem rust epidemic and its resistance may be attributed to the presence of the effective gene $\mathrm{Sr} 2$ While, the wheat varieties Abolla, Bobicho, Galema, Hawi, Kubsa, Wetera and Sofumer showed a high rust severity (40\% - $50 \%)$.

The rust severity of the cvs. Misr 1 and Misr 2 was 20 MR and 10 MS, respectively in season 2011/12, while in season2012/13 the rust severity of the same genotypes were $40 \%$ and $30 \%$. This high severity occurred in these cultivars in season 2012/13 may be due to the appearance of new stem rust race (s). Emebet et al., 
(2006) found that the wheat varieties Hawi and Simba were highly susceptible at both seedling and adult growth stages despite their resistance in previous studies for stem rust isolates from Debre Zeit and Ambo. Also, the wheat cultivars Simba and Wetera were susceptible at both growth stages (Denbel et. al., 2013) and this may be due to the widest virulence race in this study.

However, they were resistant to Debre Zeit and Ambo isolates of stem rust of wheat both in the seedling and adult plant growth stages (Emebet et al., 2006).

Area under disease progress curve (AUDPC): Data in Tables 2, 3 and Figure 1 indicates that AUDPC run in a parallel line with disease severity. In 2011/12 growing season, the results obtained showed that the highest values of AUDPC were observed on cvs. Sids 12 and Sids 13 (475 and 325). Whereas, cvs. Gemmeiza 7, Sakha 61, Gemmeiza 9, Gemmeiza 10, Giza 168, Sakha 94, Misr 2, Gemmeiza 11, Sakha 93 and Misr1 exhibited low values of AUDPC i.e. 100, 100, 145, 145, 145, 145, 145, 165, 165 and 215, respectively. According to these results in season 2011/12, the wheat cultivars were classified into two main groups, the first group included the fast rusting wheat cultivars that displayed the highest values of AUDPC (more than 215) i.e. Sids 12 and Sids 13. The second group included the slow rusting wheat cultivars that displayed the lowest values of AUDPC (less than 325) i.e. Gemmeiza 7, Sakha 61, Gemmeiza 9, Gemmeiza 10, Giza 168, Sakha 94, Misr 2, Gemmeiza 11, Sakha 93 and Misr1. In 2012/13 growing season, data in Tables 2 and 3 indicates that the cvs. Misr 1, Misr 2, Sids 12 and Sids 13 showed the highest values of AUDPC (fast rusting) i.e. 750, 475, 475 and 425, respectively. Macharia and Wanyera (2012) found that the wheat line 102091 showed low level of AUDPC, while the wheat cultivars Chozi and Duma showed high levels of AUDPC to stem rust.

Grain yield and yield losses: The 1000 kernel weight and grain yield per plot differences between protected and infected wheat genotypes due to the differences in the level of disease severity of stem rust as shown in Tables 2 and 3. In 2011/12, the loss \% of the 1000 kernel weight ranged from $2.03 \%$ to $6.71 \%$. The cvs. Sids 12 and Sids 13 gave the highest values of loss \% of 1000 kernel weight (6.71 and 5.07, respectively) compared to the other genotypes. In 2012/13, the loss \% in the 1000 kernel weight ranged from $2.20 \%$ to $6.17 \%$. The cvs. Misr 1, Misr 2, Sids 12 and Sids 13 gave the highest values of loss $\%$ of the 1000 kernel weight (6.17\%, $5.69 \%, 5.83 \%$ and $5.44 \%$, respectively) followed by cvs. Gemmeiza 10, Gemmeiza 9, Giza 168, Gemmeiza 11, Gemmeiza 7, Sakha 61, Sakha 94 and Sakha 93.

Table 3: Effect of stem rust infection on yield components of 12 Egyptian wheat cultivars at Sakha agricultural research station during season 2012/13.

\begin{tabular}{|c|c|c|c|c|c|c|c|c|}
\hline \multirow{2}{*}{ Cultivar } & \multirow{2}{*}{$\begin{array}{c}\text { Final rust } \\
\text { severity (\%) }\end{array}$} & \multirow{2}{*}{ AUDPC } & \multicolumn{3}{|c|}{1000 kernel weight (gm) } & \multicolumn{3}{|c|}{ Plot weight (kg) } \\
\hline & & & Infected & Protected & Loss $(\%)$ & Infected & Protected & Loss (\%) \\
\hline Gemmeiza7 & $5 \mathrm{~S}$ & 120 & 41.60 & 42.70 & 2.58 & 17.50 & 17.85 & 1.96 \\
\hline Gemmeiza9 & $10 \mathrm{~S}$ & 165 & 42.20 & 43.30 & 2.54 & 22.40 & 23.50 & 4.68 \\
\hline Gemmeiza10 & $10 \mathrm{~S}$ & 145 & 41.37 & 42.30 & 2.20 & 22.70 & 23.80 & 4.62 \\
\hline Gemmeiza11 & $10 \mathrm{~S}$ & 165 & 42.39 & 43.50 & 2.55 & 24.46 & 25.20 & 2.94 \\
\hline Sakha 61 & $5 S$ & 100 & 38.75 & 40.12 & 3.41 & 13.80 & 14.50 & 4.83 \\
\hline Sakha 93 & $10 \mathrm{~S}$ & 165 & 36.93 & 38.50 & 4.08 & 20.52 & 21.52 & 4.65 \\
\hline Sakha 94 & $10 \mathrm{~S}$ & 165 & 41.10 & 42.80 & 3.97 & 21.20 & 22.30 & 4.93 \\
\hline Giza 168 & $10 \mathrm{~S}$ & 145 & 42.75 & 43.85 & 2.51 & 23.15 & 24.40 & 5.12 \\
\hline Sids 12 & $30 \mathrm{~S}$ & 475 & 41.97 & 44.57 & 5.83 & 22.80 & 24.30 & 6.17 \\
\hline Sids 13 & $20 \mathrm{~S}$ & 425 & 40.00 & 42.30 & 5.44 & 22.15 & 23.40 & 5.34 \\
\hline Misr 1 & $40 \mathrm{~S}$ & 750 & 38.00 & 40.50 & 6.17 & 21.25 & 23.15 & 8.21 \\
\hline Misr 2 & $30 \mathrm{~S}$ & 475 & 39.75 & 42.15 & 5.69 & 21.90 & 23.50 & 6.81 \\
\hline L.S.D. at $5 \%$ & & & 0.176 & & & 0.119 & & \\
\hline $\begin{array}{l}\text { The loss } \% \text { of } \\
.47 \% \text { to } 6.29 \\
\text { he highest val }\end{array}$ & $c 1$ & (1) & nged fr & $\begin{array}{l}5.89 \% \\
\text { the los } \\
8.21 \%\end{array}$ & The cvs. Mi & $\begin{array}{l}\text { the other } \\
\text { per plot } \\
1 \text {, Misr 2, }\end{array}$ & $\begin{array}{l}\text { genotypes. } \\
\text { anged from } \\
\text { Sids } 12 \text { and } 5\end{array}$ & $\begin{array}{l}\text { n } 2012 / 13 \\
1.96 \% \text { th } \\
\text { ids } 13 \text { gav }\end{array}$ \\
\hline
\end{tabular}




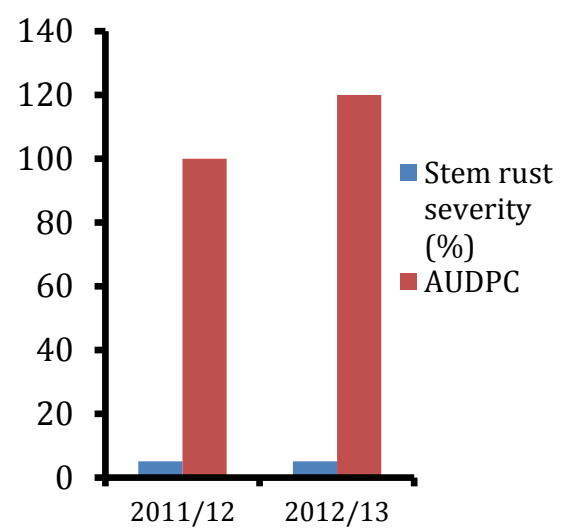

Gemmeiza 7
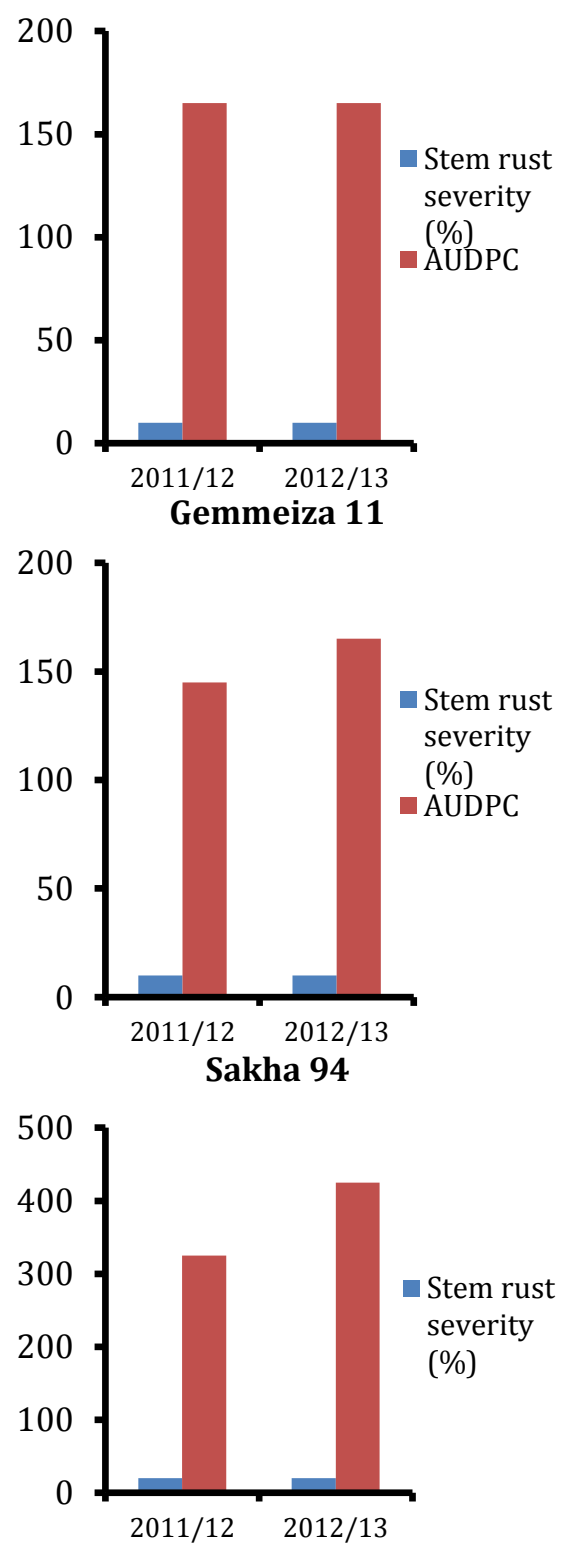

Sids 13

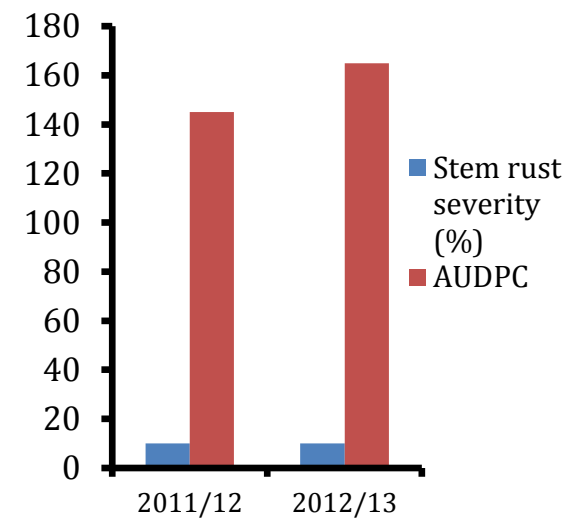

Gemmeiza 9

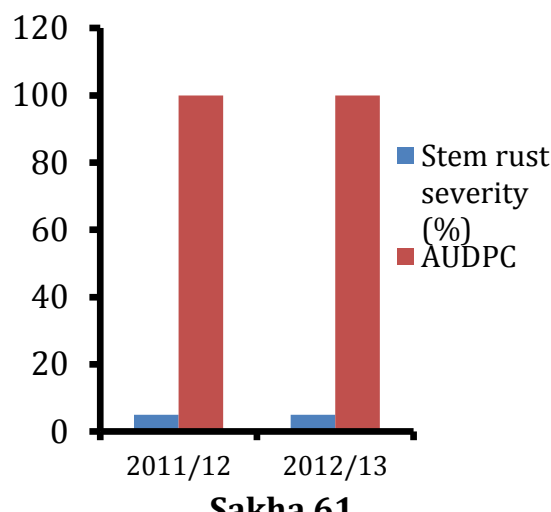

Sakha 61
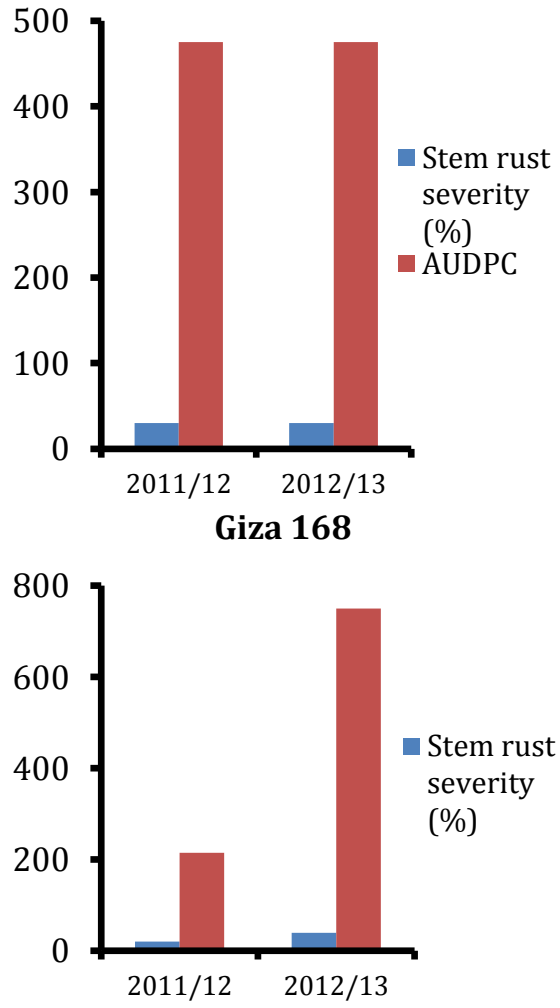

Misr 1

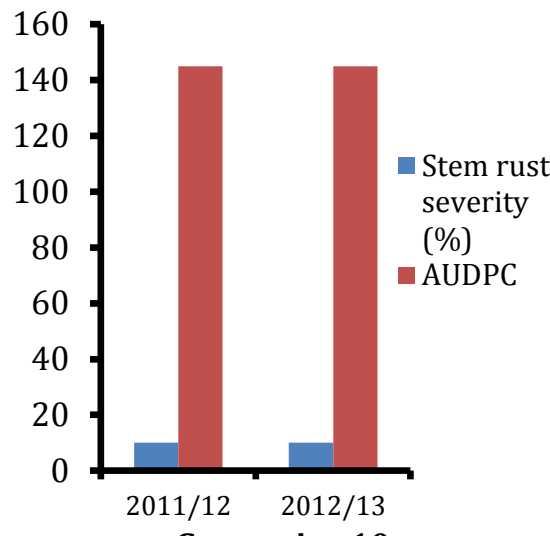

Gemmeiza 10
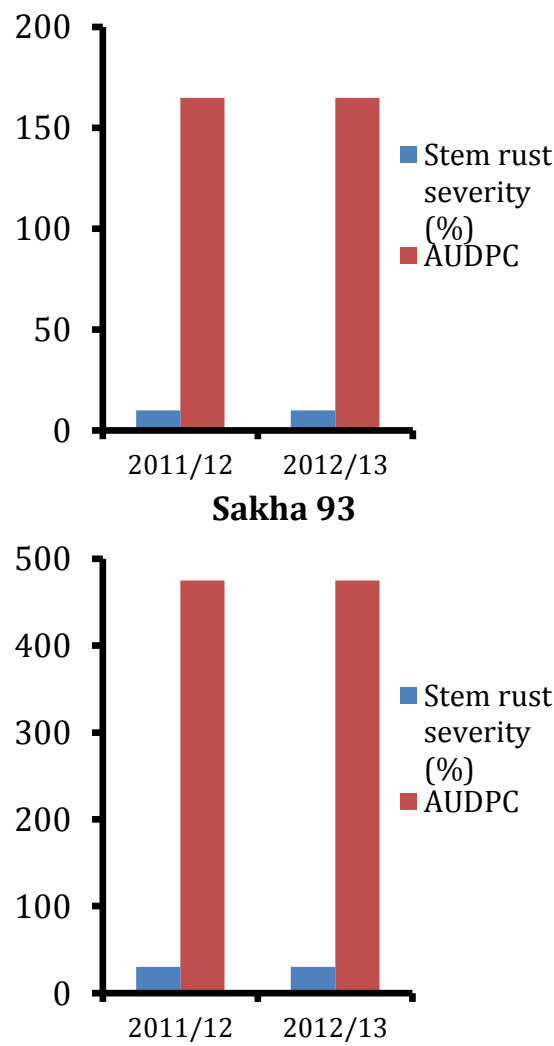

Sids 12

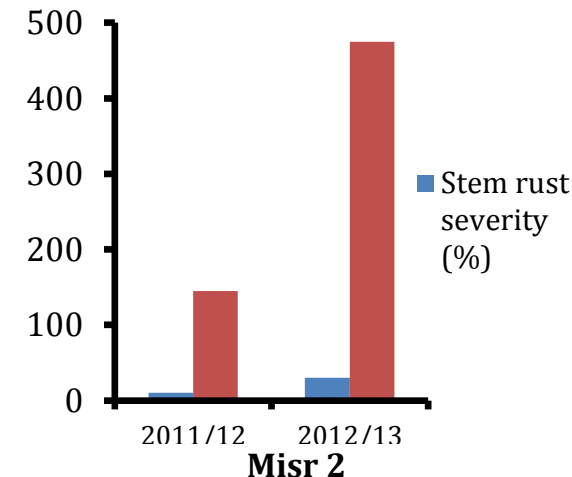

Figure 1. Final rust severity (\%) and area under disease progress curve (AUDPC) for Puccinia graminis f. sp. tritici on 12 Egyptian wheat cultivars under field conditions at Sakha agricultural research station in 2011/12 and 2012/13 growing seasons. 
the highest values of loss $\%$ of yield per plot $(8.21 \%$, $6.81 \%, 6.17 \%$ and $5.34 \%$, respectively). While, the cvs. Gemmeiza 7, Gemmeiza 11, Gemmeiza 10, Sakha 93, Gemmeiza 9, Sakha 61, Sakha 94 and Giza 168 showed the lowest values of loss \% of yield per plot. This trend is in a harmony with losses reported in previous studies obtained by (Wanyera et al., 2009 and Loughman et al., 2005). Ochoa and Parlevliet (2007) reported that yield loss was correlated strongly with area under disease progress curve, which means that high levels of partial resistance are needed to prevent significant yield loss.

This study showed that stem rust reduced yield irrespective of the type and level of resistance possessed by the cultivars (Singh et al., 2008 and Pretorius et al., 2007). The effect of rust on grain yield may be due to the energy expenditure in plant defense mechanisms rather than for growth and grain information (SmedegaardPetersen and Tolstrup, 1985). Moreover, the tissue damage caused by hypersensitive reactions also contributes to yield reduction (Khanna et al., 2005). The present study showed that infection with stem rust can severely reduce grain yield on susceptible cultivars. Therefore, growing slow rusting cultivars will reduce the loss in grain yield.

Association between AUDPC with loss in the 1000 kernel weight and loss in plot weight: The association of the 1000 kernel weight and loss in plot weight with AUDPC was determined through regression analysis during 2011/12 and 2012/13 growing seasons. Positive relation between AUDPC and loss in 1000 kernel weight during the two growing seasons $\left(\mathrm{R}^{2}=0.492\right.$ and 0.466$)$ (Fig. 2). Also, regression analysis revealed a significant linear relationship $\left(\mathrm{R}^{2}=0.783\right.$ and 0.674$)$ between loss in plot weight and AUDPC. On overall basis cultivars with maximum disease severity had lower mean grain yield and vice versa (Shaner et al., 1978). Ochoa and Parlevliet (2007) reported that yield loss was correlated strongly with AUDPC. El-Shamy et al. (2011) found that a significant correlation between mean disease severity and percentage loss for 1000-kernel and grain yield/plant.
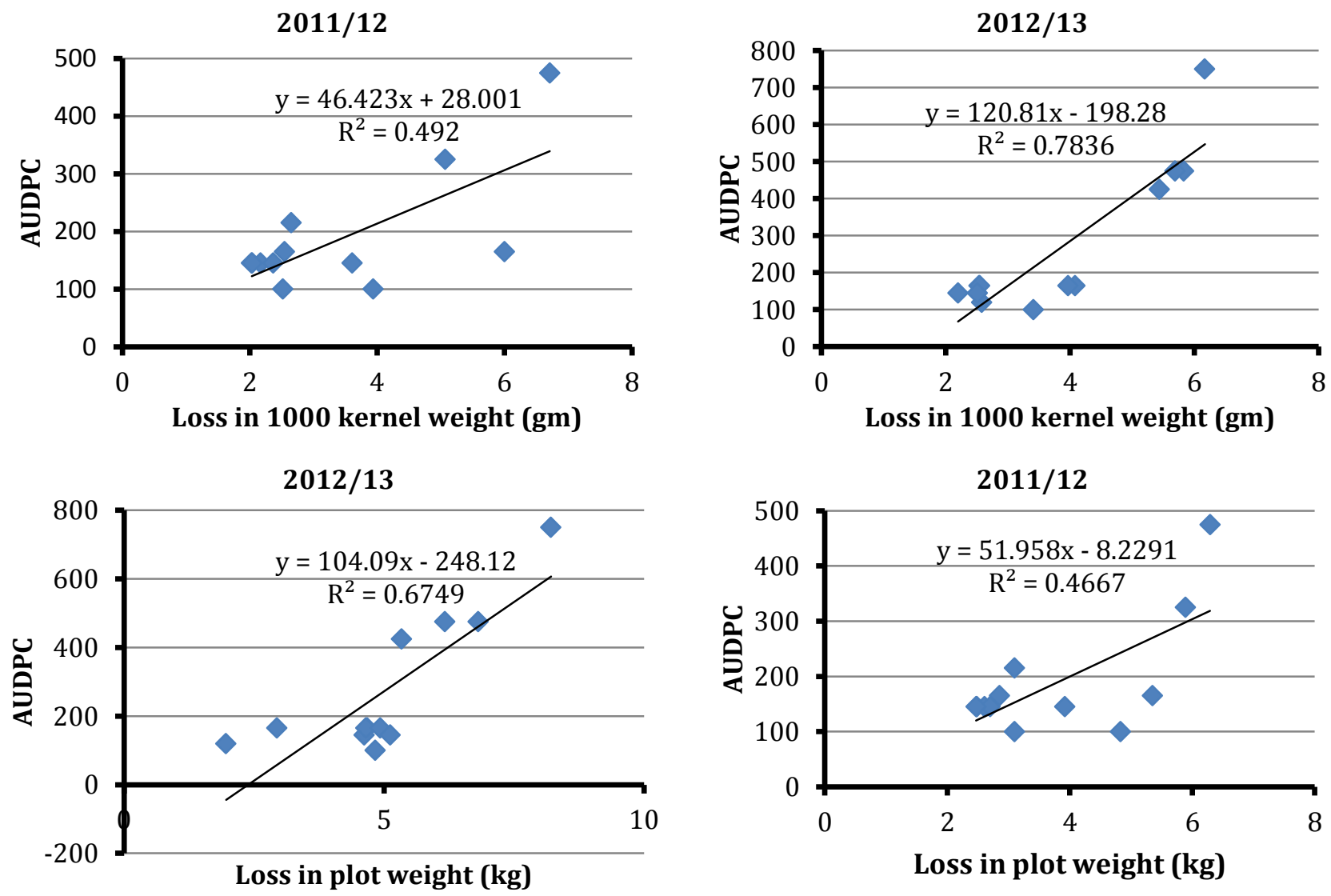

Figure 2. Association between AUDPC with loss in 1000 kernel weight and loss in plot weight for 12 Egyptian wheat cultivars tested during 2011/12 and 2012/13 growing seasons. 


\section{REFERENCES}

CIMMYT, 2005. Sounding the alarm on global stem rust. An assessment of Ug99 in Kenya and Ethiopia and potential impact in neighboring regions and beyond. 29 May 2005, pp. 26.

Colpauzos, J., A.P Roelfs, M.E. Madson, F.B. Martin and R.D. Wilconxson. 1976. A new model to measure yield losses caused by stem rust in spring wheat. Agric. Exp. Sta. Univ. Minnesota, Tech. Bull. 307:123.

Denbel, W., A. Badebo and T. Alemu. 2013. Evaluation of Ethiopian commercial wheat cultivars for resistance to stem rust of wheat race UG99. Intl. J. of Agro. and Plant Prod. 4:15-24.

El-Shamy, M.M., A.S Minaas and M.H. Abd El-Kader. 2011. Effect of sowing density of some susceptible bread wheat cultivars on tolerance to leaf rust disease. Zagazig J. Agric. Res. 38:339-352.

Emebet, F., A. Belayneh And A. Zerihun. 2006. Seedling and adult plant resistance in Ethiopian wheat varieties to local Puccinia graminis isolates. In: Kinyua MG, Kamwaga J, Owuoche JO, Ndiema AC, Njau PN, Friesen K, Ouya D, (eds). Proceedings of the $12^{\text {th }}$ Regional Wheat Workshop for Eastern, Central and Southern Africa. Nakuru, 22-26 November 2004. CIMMYT and KARI, Mexico. D.F. pp: $86-89$.

Hassan, G. 2004. Diallel analysis of some important parameters in wheat (Triticum aestivum $\mathrm{L}$ ) under irrigated and rainfed conditions. Ph.D. thesis submitted to NWFP Agricultural University Peshawar, Pakistan.

Hiebert, C.W., T.G Fetch, T. Zegeye, J.B. Thomas, D.J. Somers, D.G Humphreys, B.D. McCallum, S. Cloutier, D. Singh and D.R. Knott. 2011. Genetics and mapping of seedling resistance to Ug99 stem rust in Canadian wheat cultivars 'Peace' and 'AC Cadillac'. Theor Appl. Genet. 122:143-149.

Jin, Y., L. Szabo, M. Rouse, T. Fetch, Z.A Pretorius, R. Wanyera and P. Njau. 2009. Detection of virulence to resistance gene Sr36 within race TTKS lineage of Puccinia graminis f. sp. tritici. Plant Dis. 93:367370.

Jin, Y., L. Szabo, Z.A. Pretorius, R. Singh, R. Ward and T. Fetch. 2008. Detection of virulence to resistance gene $\operatorname{Sr} 24$ within race TTKS of Puccinia graminis $\mathrm{f}$. sp. tritici. Plant Dis. 92:923-926.

Jin, Y., R.P. Singh, R.W. Ward, R. Wanyera, M. Kinyua, P.
Njau, T. Fetch, Z.A. Pretorius and A. Yahyaoui. 2007. Characterization of seedling infection types and adult plant infection responses of monogenic $\mathrm{Sr}$ gene lines to race TTKS of Puccinia graminis $\mathrm{f}$. sp. tritici. Plant Dis. 91:1096-1099.

Khanna, R., U.K. Bansal and R.G. Saini. 2005. Genetics of adult plant stripe rust resistance in CSP44, a selection from Aust. wheat. J. of Genet. 84:337-340.

Leonard, K.J. and L.J. Szabo. 2005. Stem rust of small grains and grasses caused by Puccinia graminis. Mol. Plant Pathol. 6: 99-111.

Leonard, K.J. and L.J. Szabo. 2005. Stem rust of small grains and grasses caused by Puccinia graminis. Mol. Plant Pathol. 6:99-111.

Loughman, R., K. Jayasena and J. Majewski. 2005. Yield loss and fungicide control of stem rust of wheat. Aust. J. of Agric. Res. 56:91-96.

Macharia, J.K. and R. Wanyera. 2012. Effect of stem rust race Ug99 on grain yield and yield components of wheat cultivars in Kenya. J. of Agric. Sci. and technol. 2:423-431.

Ochoa, J. and J.E. Parlevliet. 2007. Effect of partial resistance to barley leaf rust, Puccinia hordei on the yield of three barley cultivars. Euphytica. 153:309-312.

Pandey, H.N., T.C.M. Menon and M.V. Rao. 1989. A simple formula for calculating area under disease progress curve. Rachis. 8:38-39.

Park, R., T. Fetch, D. Hodson, Y. Jin, K. Nazari, M. Prashar and Z. Pretorius. 2011. International surveillance of wheat rust pathogen: progress and challenges. Euphytica. 179:109-117.

Peterson, R.F., A.B. Campbell and A.E. Hannah. 1948. A diagrammatic scale for estimating rust intensity on leaves and stems of cereals. Can. J. Res. 60:496500.

Pretorius, Z.A., K.W. Pakendori, G.F. Marais, R. Prins and J.S. Komen. 2007. Challenges for sustainable cereals rust control in South Africa, in: J.C. Fegent (ED.) Special Issue: Global Landscapes in Cereal Rust Control, Aust. J. of Agric. Res. 58:593-601.

Pretorius, Z.A., R.P. Singh, W.W. Wagoire and T.S. Payne . 2000. Detection of virulence to wheat stem rust resistance gene $\mathrm{Sr} 31$ in Puccinia graminis f. sp. tritici in Uganda. Plant Dis. 84:203.

Roelfs, A.P. and J.W Martens. 1988. An international system of nomenclature for Puccinia graminis $\mathrm{f}$. sp. tritici. Phytopathol. 78:526-533. 
Roelfs, A.P., 1985. The cereal rusts, Vol. II: diseases, distribution, epidemiology and control. Orlando (FL): Academic Press. Chapter 1, Wheat and rye stem rust. p. 3-37.

Roelfs, A.P., R.P. Singh and E.E. Saari. 1992. Rust diseases of wheat: Concepts and methods of disease management. CIMMYT, Mexico, D.F.

Shaner, G., H.W. Ohm and R.E. Finnay . 1978. Response of susceptibility and slow leaf rusting of wheats to infection by Puccinia recondita. Phytopathol. 68:47-475.

Singh, R.P., D.P Hodson, J. Huerta-Espino, Y. Jin, P. Njau, R. Wanyera, S.A. Herrera-Foessel and W.R. Ward. 2008. Will stem rust destroy the world's wheat crops? Adv. Agron. 98:271-309.

Smedegaard-Petersen, V. and K. Tolstrup. 1985. The limiting effect of disease resistance on yield. Annual Review Phytopathol. 23:475-490.
Snedecor, G.W., 1957. Statistical Methods, 5th eds.lowa State College Press, Ames, Iowa. Wang, Z.L.; L.H. Li; Z.H. He; X. Duan; Y.L. Zhou; X.M. Chen; M. Lillemo; R.P. Singh; H. Wang and H. Xia XC (2005): Seedling and adult plant resistance to powdery mildew in Chinese bread wheat cultivars and lines. Plant Dis. 89:457-463.

Wanyera, R., M.G. Kinyua, Y. Jin and R.P Singh. 2006. The spread of stem rust caused by Puccinia graminis $\mathrm{f}$. sp. tritici, with virulence on $\mathrm{Sr} 31$ in wheat in Eastern Africa. Plant Dis. 90:113.

Wanyera R., J.K. Macharia, S.M. Kilonoz and J.W. Kamundia. 2009. Foliar fungicides to control wheat stem rust, race TTKS (Ug99), in Kenya. Plant Dis. 93:929-932. 